\title{
LIFE HISTORY OF THE GALL-MAKER Eugeniamyia dispar MAIA, MENDONÇA-JR. \& ROMANOWSKI, 1996 (DIPTERA, CECIDOMYIIDAE)
}

\author{
MENDONÇA, M. de S., Jr. ${ }^{1,2}$ and ROMANOWSKI, H. P. ${ }^{1}$ \\ ${ }^{1}$ CPG Biologia Animal, Instituto de Biociências, UFRGS, Av. Bento Gonçalves, 9500, Prédio 43435, Bloco IV, \\ CEP 91501-970, Porto Alegre, RS, Brazil \\ ${ }^{2}$ Department of Biology, Imperial College at Silwood Park, Ascot, Berkshire, SL7 PY5, UK \\ Correspondence to: Milton de S. Mendonça-Jr., Departamento de Zoologia and CPG Biologia Animal, Instituto de \\ Biociências, UFRGS, Av. Bento Gonçalves, 9500, Prédio 43435, Bloco IV, CEP 91501-970, Porto Alegre, RS, \\ Brazil, e-mail: milton_mendonca@uol.com.br \\ Received March 29, 2001 - Accepted May 24, 2001 - Distributed May 31, 2002
}

(With 2 figures)

\begin{abstract}
The development of the galls of the midge Eugeniamyia dispar Maia, Mendonça-Jr. \& Romanowski, 1996 (Diptera: Cecidomyiidae) was monitored weekly on its host plant, Eugenia uniflora (Myrtaceae). The work was carried out in the urban area of Porto Alegre, RS, Brazil, from October 1993 to September 1995. Galls were collected from the field and raised in the laboratory to obtain adults. The females oviposit on young leaves of the host plant, with the first instar larvae inducing the gall, which is unilocular. The last instar larvae drop to the soil to pupate and later emerge as adults. The galls occur from late August to early June, when young leaves of the host can be found, with populations peaking during the summer. So far this species is only known from the two southernmost states of Brazil (RS and SC).
\end{abstract}

Key words: gall midge, population ecology, Eugenia uniflora, Myrtaceae.

\section{RESUMO}

\section{História de vida do galhador Eugeniamyia dispar Maia, Mendonça-Jr. \& Romanowski, 1996 (Diptera, Cecidomyiidae)}

O desenvolvimento das galhas de Eugeniamyia dispar (Diptera: Cecidomyiidae) foi monitorado semanalmente na planta hospedeira, Eugenia uniflora (Myrtaceae). O trabalho foi desenvolvido na área urbana de Porto Alegre, RS, Brasil, entre outubro de 1993 e setembro de 1995. Galhas foram coletadas em campo e levadas a laboratório a fim de obter adultos. As fêmeas do inseto ovipositam nas folhas jovens da planta hospedeira, com o primeiro ínstar larval induzindo a galha, que é unilocular. O último ínstar larval sai da galha e cai ao solo para empupar, emergindo tempo depois como adultos. As galhas ocorrem desde o fim de agosto até início de junho, quando folhas novas do hospedeiro podem ser encontradas; as populações atingem picos durante o verão. Essa galha foi encontrada somente nos dois Estados mais ao sul do Brasil (RS e SC).

Palavras-chave: inseto galhador, ecologia de populações, Eugenia uniflora, Myrtaceae.

\section{INTRODUCTION}

Life history is a species pattern of growth, differentiation and reproduction (Begon et al., 1990), and information about it is essential to understand the population ecology and evolution of a species (Stearns, 1992).

The Cecidomyiidae are numerous and varied in life history strategies, comprising mostly herbivore gall-makers (Hawkins \& Gagné, 1989), but 
also detritivore fungus-feeders (Gagné, 1986), and predators (e.g. aphid parasitoids, Tang et al., 1994). The gall-makers live as plant parasites (Price, 1984), and usually have a highly specific relationship with the host, inducing plant tissue growth and differentiation (Rohfritsch, 1992), which provide them nutrition, a suitable microenvironment and sometimes protection from natural enemies (Price et al., 1987). Although much is known about the ecology of some of the species of Cecidomyiidae, mainly from Europe and United States, the number of species (and even of genera) described in this family is still growing remarkably around the world, for example in Western Europe (e.g. Fedotova, 1994, 1993a, 1993b), Brazil (Maia, 1995a, 1995b, 1993a, 1993b; Maia \& Couri, 1993; Maia et al., 1996) and USA (Gagné \& Bennett, 1993; Gagné $\&$ Strong, 1993). These works are essentially of taxonomic nature, and much more is needed to understand the ecology and evolution of this group as a whole. In the Neotropical region, especially, there is a small but growing literature on the ecology of Cecidomyiidae (e.g. Fernandes et al., 1987; Arduin et al., 1994).

The system presented here is centred in the host plant and its gall-maker. Eugenia uniflora (Myrtaceae), the "pitangueira", is a very common shrub in southern and southeastern Brazil, both in riparian forests and coastal plains (Legrand \& Klein, 1969). This species has some economical and pharmacological importance (Neves \& Donato, 1989). The fruit is edible and the leaves release a typical scent when crushed because of its essential oils (Schultz, 1984). Eugeniamyia dispar Maia, Mendonça \& Romanowski, 1996 (Cecidomyiidae), a previously unknown species and genus of insect, develops on galls induced on the new leaves and shoots of the plant. This work is part of a wider study on the ecology of the system (Mendonça, 1996; Mendonça et al., 1998). Aspects such as (i) the anatomical and ontogenetic aspects of the gall tissues, (ii) leaf phenology of the host plant per $s e$ and as the oviposition resource for the gallmaker, (iii) presence of other arthropods associated with the gall and gall-maker, and (iv) an array of data about the population ecology of the gallmaker, including life-table analysis of larval stages, will be dealt with in detail in further papers.

\section{MATERIALS AND METHODS}

Sampling was carried out on E. uniflora plants in the urban area of Porto Alegre, RS, Brazil (30 1 'S, $\left.51^{\circ} 13^{\prime} \mathrm{W}\right)$, from October 1993 to September 1995, on a weekly basis except for the winter (June to August) when they were fortnightly. The sampling area is adjacent to a large plot (ca. $10 \mathrm{ha}$ ) of disturbed but recovering vegetation. The area is also near (ca. $2 \mathrm{~km}$ ) to Porto Alegre Botanical Gardens (30 ha).

Close observations were made at two specific sites. Site A is located at Visconde Duprat street, in the front garden of a house. It has three established host plants, with two other plants later introduced in flowerpots. Site B is located at Ivo Coseuil street, on the walkway, and has at least four recognisable individuals of the host plant. At each site there is a larger plant (1.5-1.8 m tall) while the others are at most $1 \mathrm{~m}$ tall (a mature plant can reach 6-12 m tall, Legrand \& Klein, 1969).

Information was gathered on the leaf phenology of E. uniflora, morphology of the gall, other Arthropoda associated with the gall or the midge, and population ecology of the gall-maker (total counting of galls and mortality factors acting on them), including its development and life cycle. Additionally, in the laboratory, galls were opened to examine contents, and gall-bearing shoots were planted in small pots, covered by a transparent plastic cylinder, to obtain adults.

Some host plants were also extensively searched for galls, in other cities of Rio Grande do Sul state and other southern Brazilian states (Santa Catarina and São Paulo), ranging from $23^{\circ} \mathrm{S}$ to $30^{\circ} \mathrm{S}$, approximately.

\section{RESULTS}

The gall occurs mostly on leaves and occasionally on shoots. Each leaf gall is crossed by the leaf blade approximately in the middle. Each gall is induced by only one larva (monothalamous), but can coalesce with the nearest galls if growing too close. The gall tissues are spongy, fragile and rich in fluid, lacking almost all or all chlorophyll, which gives the gall a pale green or frequently white colour. The gall is spherical to egg-shaped, 3 to 
$5 \mathrm{~mm}$ in diameter and 3.5 to $5 \mathrm{~mm}$ in height, and the gall chamber is small due to the intense growth of the surrounding gall tissues. The induction happens only on the new leaves of the plant. These can be distinguished from mature leaves by their dark red to red colour, caused by the presence of anthocianins (delayed-greening pattern, Kursar \& Coley, 1992). As shoots grow, they can produce up to four pairs of new leaves before pausing to mature them completely. The young leaves are the resource for oviposition, and so can limit the occurrence of the gall in time. The galls can be found from the end of August, just after a leaf flush of the host plants, to the beginning of June, when the last mature gall was recorded. Up to nine generations per year were registered in some plants.

\section{LIFE HISTORY (Fig. 1)}

Eggs

The eggs of E. dispar are about $0.3 \mathrm{~mm}$, and can hardly be seen by the naked eye. They are sausage-shaped (Fig. 2a), light orange and translucent.

The eggs are placed mostly on the lower but also on the upper surface of the leaves, and occasionally on shoots adjacent to the leaves. Observations of the eggs and galls spatial distribution on each leaf indicated a slight gradient of aggregation towards the base of the leaf. They are also rare on leaf borders, except for a minority of eggs placed on the upper side of the leaves, which were all near the border.

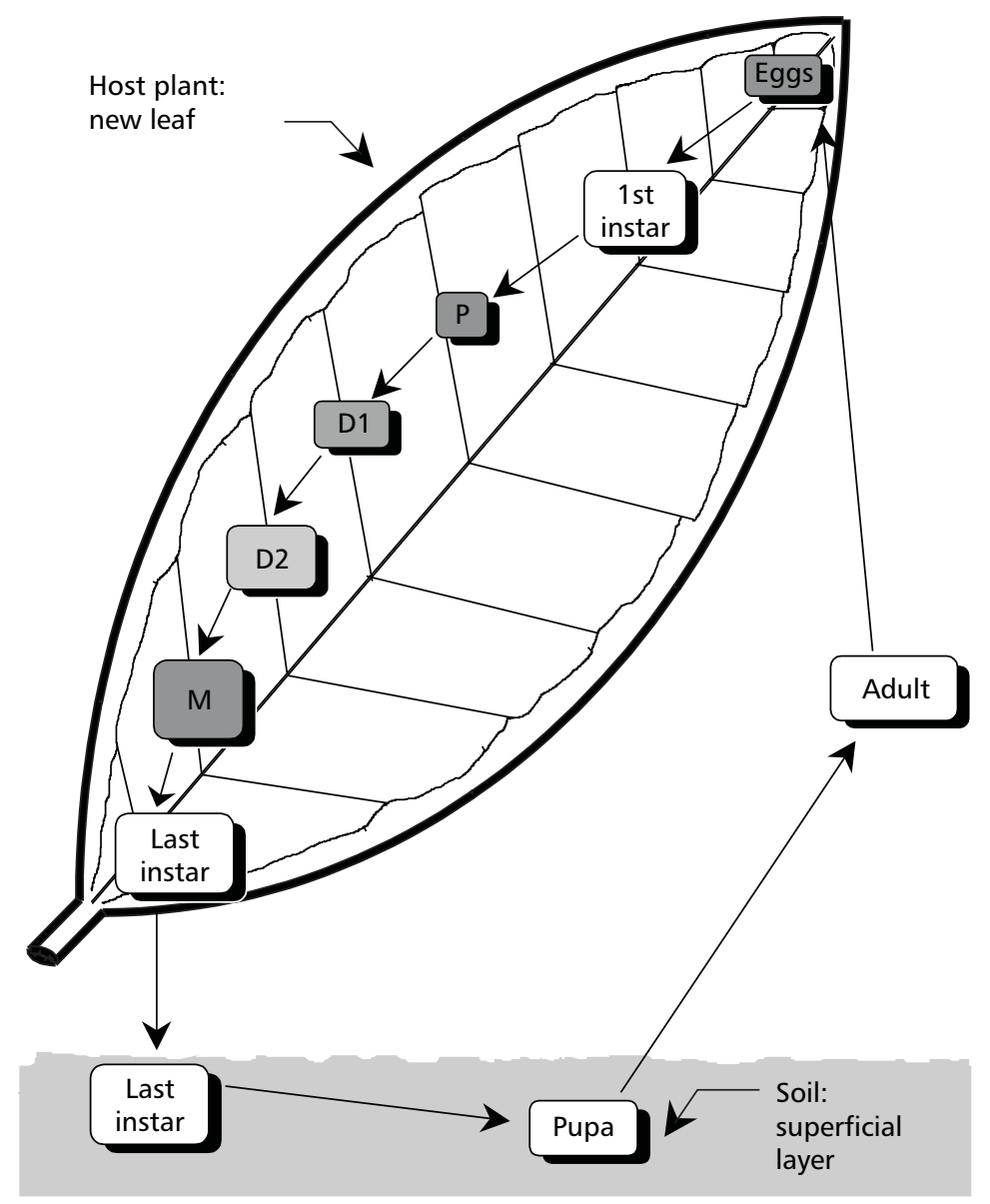

Fig. 1 - Eugeniamyia dispar life-cycle and the microhabitats in which it occurs. Rectangles show the stage of development of the insect or the gall (P: point-like stage; D1 and D2: development stages; M: mature gall). Arrows indicate the passing of time (galls do not move on the leaf). 


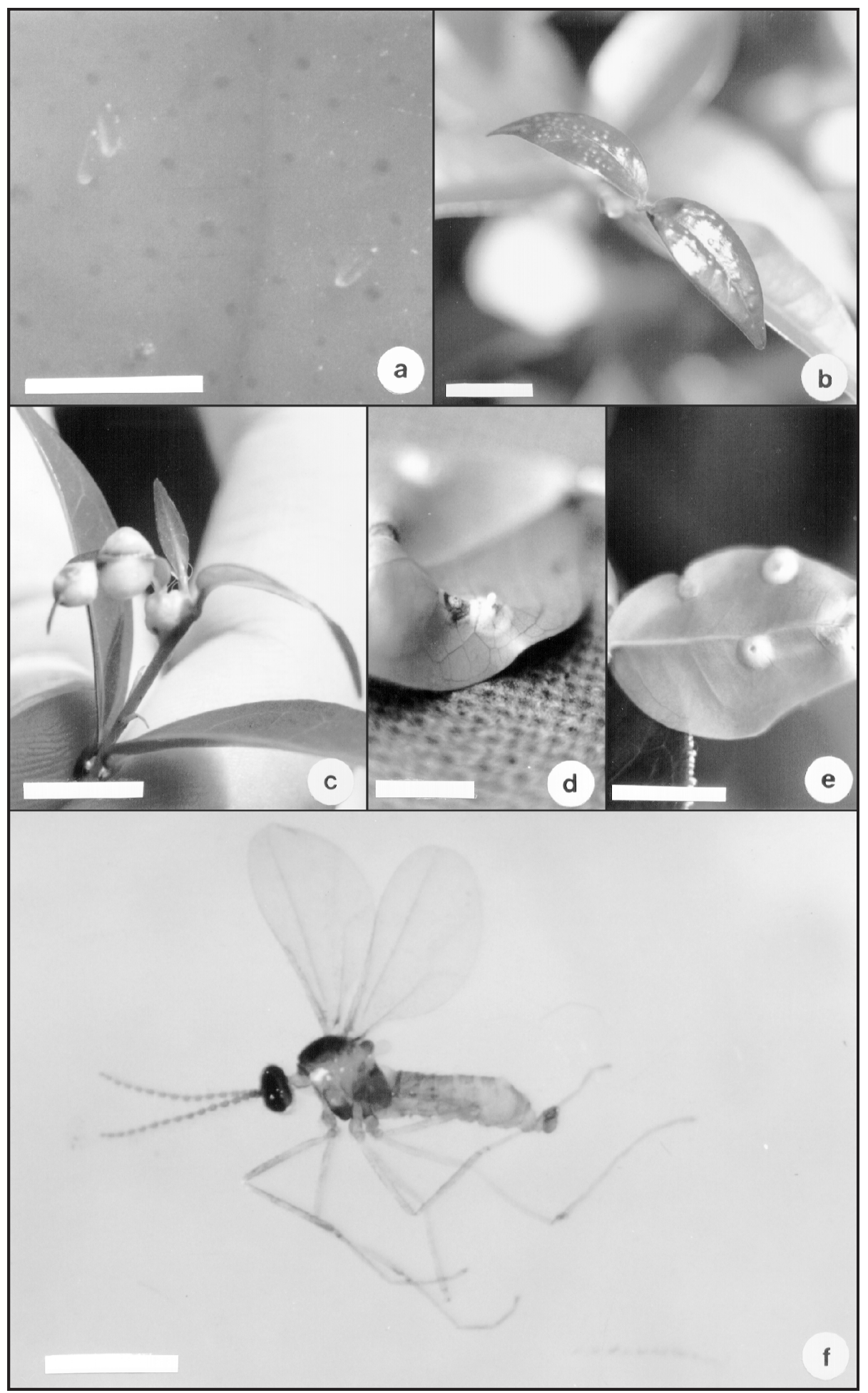

Fig. 2 - Phases of the life of Eugeniamyia dispar: a) eggs on the surface of a host leaf; b) point-like stage of gall development (notice the high number of galls on this leaf); c) mature galls with typical white colour; d) mature larvae leaving a gall (half of the body outside); e) orifice resulting from the exit of larvae; and f) adult female of the insect. Bars represent $1 \mathrm{~mm}$ in a and $\mathrm{f}$, and $1 \mathrm{~cm}$ from $\mathrm{b}$ to e. 


\section{1st instar larva}

Gall induction occurs almost always on very young leaves, and gall development is completed before leaves are fully mature. Hatching time appears to be about 2 or 3 days after oviposition. First instar larvae are as large as the egg, and transparent except for an internal red spot in the thorax and the proximal part of the abdomen.

Leaves with young galls also showed egg chorions close by, suggesting that the larvae move little before settling down. After settling, the now immobile larva has its body flattened against the leaf, and ridges of plant tissue start to grow around the larva until it is enclosed by them. Surrounded by gall tissues, the larva develops on the nutritive tissue, which is the ceiling of the gall chamber.

\section{Gall development, last instar larva and pupa}

The gall starts as no more than a point-like structure in the leaf blade (stage P, Fig. 1), with a small elevation on the side of the leaf opposed to the site of induction (Fig. 2b). In a few days it expands in surface, but little in volume (stage D1, Fig. 1). Afterwards, it expands mostly in volume (stage D2, Fig. 1), on both sides of the leaf, assuming its final shape and colour (Fig. 2c). The maturation time of the gall varies from one and a half to two or three weeks, being shorter in the summer.

The last larval instar is highly mobile, being able to crawl long distances (observations made when galls were opened in the laboratory). The larva is whitish, 3.0-3.2 $\mathrm{mm}$ long and has a rough integument. The thoracic spatula is red, well developed, 0.20-0.23 mm long (Maia et al., 1996), and used to open the way out of the gall. The larva does this by first retracting the head, leaving the apex of the spatula in evidence on the border of the first thoracic segment, and then leaning the body against the inner parts of the gall, it makes lateral movements with the head, pulling the soft tissues aside. These actions become fully evident under the stereomicroscope (10x magnitude) when the larva is about to reach the epidermis of the gall, which is almost transparent. Upon reaching the epidermis, the larva forces itself through a narrow orifice it rips on this plant tissue and falls to the ground (Figs. 2d and 2e). A few larvae were even observed to get stuck in the orifice and die. The now open gall soon dries out after the larva leaves.
Once reaching the ground, the larva buries itself pulling aside the soil grains. The tunnel formed is too small to be identifiable. The larva pupates in the soil, and leaves it as an adult. The time from leaving the gall until adult emergence is between five days to two weeks, except in the winter, when galls are not found on the plant for up to two months and a half. In this case we cannot exclude an alternative host, though it seems improbable (most plants stop producing leaves during winter in subtropical Brazil), and we favour the hypothesis of dormancy/diapause in the soil.

\section{Adult}

The adults are only $1.8-2.0 \mathrm{~mm}$ in body length and 2.5-2.9 $\mathrm{mm}$ in wing length (Fig. 2f). Most of the body is covered by scales, the ovipositor is barely protractible and the male genitalia is unusually built (Maia et al., 1996). Only once during the whole period of observations was an adult (female) found in the field, wandering in the canopy of a host plant at sunset time. The insect walked along and around the shoots, stopping in the new leaves or leaf buds. Soft winds shook the shoots occasionally, forcing the female to fly and reach another shoot. Many adults reared in the laboratory used to walk on the soil of the pots, but almost all the midges found above soil level on the walls of the plastic cages were females. It was not possible to reasonably estimate the length of adult life; however, adult longevity may be about a few days. Oviposition was never observed.

\section{ABUNDANCE AND DISTRIBUTION}

In the field, many plants never bear galls, some do it only occasionally, and a few bear them constantly throughout their period of occurrence. The generations differ widely in the number of galls: in spring and autumn there were usually less than 100 galls per plant per generation, and in the summer at least 200 galls, sometimes 500 galls per plant, each generation. The distribution of these galls was such that the majority of leaves and shoots had only one gall on them, though maximum values could be very high (33 on a single leaf and 71 on a single shoot).

Up to now this gall has been found only in Rio Grande do Sul and Santa Catarina states (sou- 
thernmost states of Brazil) - approximately between latitudes $27^{\circ} 30^{\prime}$ and $30^{\circ} \mathrm{S}$.

\section{DISCUSSION}

The life cycle of Eugeniamyia dispar takes place in three distinct microhabitats (Fig. 1). Eggs are laid on and larvae live inside host plant tissues, developing and accumulating energy; the last instar larvae drop to the soil and pupate; and the adults are the flying dispersers. Gall development is a quick process, and indeed the whole life cycle of this insect is relatively fast, lasting about a month. In this way successive generations can follow each other in a single year.

The eggs of E. dispar are simply laid on the surface of the leaves, which is apparently normal for the Cecidomyiidae family (Dreger-Jauffrett \& Shorthouse, 1982; Gagné, 1986), and thus the induction of the gall is performed solely by the first instar larva. The slight aggregation of the eggs towards the base of the leaf can be regarded as a pattern similar to those for other gall-makers (e.g. Whitham, 1979; but see Akimoto \& Yamaguchi, 1994), in which the quality of the gall induction site increases the closer to the petiole the insect gets.

Some larval Cecidomyiidae have very limited locomotion capabilities (e.g. Singh, 1992); in E. dispar the high mobility of the last larval instar is surely associated with the fact that this phase needs to perform both tasks of tearing the gall tissues apart and burying itself in the soil. The thoracic spatula used by the last instar larva to tear the gall tissues is also commonly associated with this function in other Cecidomyiidae (Mani, 1964), even with those who induce galls on woody tissues.

Pupation in the soil is a life history trait found in some Cecidomyiidae. In a revision by Hawkins \& Gagné (1989), 30\% out of 183 species of this family showed a change in the pupation site from the gall to the soil. A possible advantage of this could be to provide escape from natural enemies since galls are relatively easy to locate and immobile. The pupa is more prone to the attack of natural enemies (including pathogens), for it cannot react on a physical basis. Since the energy required for development into an adult had already been gathered during the larval phase, it would be adaptive for the larva to leave the gall and pupate in another place, escaping predation or disease. In fact, the number of parasitoids in the Cecidomyiidae, which pupate in the soil, is significantly lower than those, which pupate in the gall (Hawkins \& Gagné, 1989).

At the same time, the change in the pupation site still keeps the insect close to its future mating and oviposition sites (host plant leaves). As there are relatively high numbers of individuals in each host plant, and their development is synchronic (distinct generations), encounters between males and females may be common close to the emergence sites. This could account for the adults being found on the soil, in the laboratory cages. Copulation close to emergence sites is found in other species of Cecidomyiidae (Kolesik, 1993; Lampo \& Medialdea, 1994; Pivnick, 1993). Thereafter, oviposition can be achieved by females by flying up to the plant canopy. Laboratory reared females, found up on the plastic cages walls, may well reflect this. As observed in the female found in the field, these insects are easily blown by the wind, and some dispersal may occur this way, eventually breaking the overall tendency to stay close to the "home" plant.

E. dispar life history provides the basis for the understanding of its ecology, aspects of which shall be presented in further articles. The main concern in this study was the gall and larval stages. Thus, future work could focus on the adult stage, which was only superficially dealt with in the present investigation. For example, as adults could be reared in laboratory conditions, more observations and experiments on copulation and oviposition behaviour could be very informative, adding to the understanding of the factors affecting the life of this insect.

Acknowledgments - The authors would like to thank Prof. Miriam Becker for helpful suggestions on an early draft of the manuscript, and also Prof. Jorge Mariath of UFRGS Departamento de Botânica for the kind permission to use the photomicroscope. This work was supported by FAPERGS and CAPES, to whom we are also thankful.

\section{REFERENCES}

AKIMOTO, S. \& YAMAGUCHI, Y., 1994, Phenotypic selection on the process of gall formation of a Tetraneura aphid (Pemphigidae). J. Anim. Ecol., 63: 727-738.

ARDUIN, M., KRAUS, J. E. \& MONTENEGRO, G., 1994, Morfologia e fenologia de galhas foliares de Piptadenia gonoacantha (Fabales, Mimosaceae). Revta. Bras. Ent., 38: 79-89.

BEGON, M., HARPER, J. L. \& TOWNSEND, C. R., 1990, Ecology: individuals, populations and communities. $2^{\text {nd }}$ ed. Blackwell Sci. Publ., Cambridge, UK. 
DREGER-JAUFFRETT, F. \& SHORTHOUSE, J. D., 1992, Diversity of gall-inducing insects and their galls. In: J. D. Shorthouse \& O. Rohfritsch (eds.), Biology of insectinduced galls. Oxford University Press, Oxford, UK, pp. 8-33.

FEDOTOVA, Z. A., 1993a, Gall midges of the genus Ephedromyia (Diptera, Cecidomyiidae) in Kazakhstan and Turkmenia. Zoologicheskii Zhurnal, 72: 88-96.

FEDOTOVA, Z. A., 1993b, New species of gall-midges of the genus Contarinia Rd. (Diptera, Cecidomyiidae) developing on legumes (Fabaceae) in Kazakhstan. Entomologicheskoe Obozrenie, 72: 675-683.

FEDOTOVA, Z. A., 1994, New species of flower gall midges (Diptera, Cecidomyiidae) from the Mountains of Kazakhstan. Entomological Review, 73: 93-106.

FERNANDES, G. W., MARTINS, R. P. \& TAMEIRÃO NETO, E., 1987, Food web relationships involving Anadiplosis sp. (Diptera: Cecidomyiidae) leaf galls on $\mathrm{Ma}$ chaerium aculeatum (Leguminosae). Revta. Bras. Bot., 10: $117-123$.

GAGNÉ, R. J., 1986, The transition from fungus-feeding to plant-feeding in Cecidomyiidae (Diptera). Proc. Entomol. Soc. Wash., 88: 381-384.

GAGNÉ, R. J. \& BENNETT, F. D., 1993, Two new species of Lestodiplosini (Diptera: Cecidomyiidae) preying on Homoptera and Thysanoptera in southern Florida. Florida Entomologist., 76: 341-348.

GAGNÉ, R. J. \& STRONG, D. R., 1993, A new species of Dasineura (Diptera: Cecidomyiidae) galling leaves of Lupinus spp. (Fabaceae) in California. Proc. Entomol. Soc. Wash., 95: 541-546.

HAWKINS, B. A. \& GAGNÉ, R. J., 1989, Determinants of assemblage size for the parasitoids of Cecidomyiidae (Diptera). Oecologia, 81: 75-88.

KOLESIK, P., 1993, Basic bionomics of the lentil gall midge (Contarinia lentis Aczel) (Dipt., Cecidomyiidae). J. Appl. Ent., 116: 371-380.

KURSAR, T. A. \& COLEY, P. D., 1992, Delayed greening in tropical leaves: an antiherbivore defense? Biotropica, 24: $256-262$.

LAMPO, M. \& MEDIALDEA, V., 1994, Dispersal pattern of the sorghum midge (Diptera: Cecidomyiidae) in sorghum plots. Environ. Entomol., 23: 551-555.

LEGRAND, C. D. \& KLEIN, R. M., 1969, Mirtáceas (2. Eugenia). In: R. Reitz (ed.), Flora Ilustrada Catarinense. Itajai, SC, pp. 84-89.

MAIA, V. C., 1993a, A new species of Clinodiplosis Kieffer (Diptera, Cecidomyiidae) associated with Melissa officinalis Linnaeus (Labiatae) in Brazil. Revta. Bras. Zool., 10: 695-697.

MAIA, V. C., 1993b, Description of two new species of Cecidomyiidae (Diptera) associated with Eugenia spp. (Myrtaceae). Revta. Bras. Ent., 37: 717-721.

MAIA, V. C., 1995a, Chaves para classificação de galhas de Cecidomyiidae (Diptera) em Myrtaceae na restinga da barra de Maricá, Rio de Janeiro. Revta. Bras. Zool., 12: 1009-1013.
MAIA, V. C., 1995b, Três espécies novas de Dasineura Rondani (Diptera, Cecidomyiidae) associadas a Myrtaceae na Restinga da Barra de Maricá, Rio de Janeiro. Revta. Bras. Zool., 12: 1001-1008.

MAIA, V., MENDONÇA-Jr., M. de S. \& ROMANOWSKI, H. P., 1996, Eugeniamyia dispar gen.n. and sp.n. (Diptera, Cecidomyiidae, Lasipteridi) associated with Eugenia uniflora L. (Myrtaceae) in Brazil. Revta. Bras. Zool., 13: 1087-1090.

MAIA, V. C. \& COURI, M. S., 1993, Description of three new species of Bruggmannia Tavares, 1906 (Diptera, Cecidomyiidae, Asphondyliidi) from Brazil, associated with Guapira opposita (Nyctaginaceae). Revta. Bras. Biol., 53: 209-215.

MANI, M. S., 1964, Ecology of plant galls. Dr. W. Junk Publisher, The Hague, Netherlands. 434p.

MENDONÇA, M. de S., Jr., 1996, Ecologia de Eugeniamyia dispar (Diptera: Cecidomyiidae), galhador sobre Eugenia uniflora (Myrtaceae). Dissertação de Mestrado, Instituto de Biociências, UFRGS, Porto Alegre.

MENDONÇA, M. de S., Jr., ROMANOWSKI, H. P. \& KRAUS, J. E., 1998, Broad overview of a gall-system: from plant anatomy to ecological interactions. In: G. Csóka, W. J. Mattson, G. N. Stone \& P. W. Price (eds.), The biology of gall-inducing arthropods. Forest Service, USDA General Technical Report, NC-199, p. 327.

NEVES, L. de J. \& DONATO, A. M., 1989, Contribuição ao estudo de Eugenia uniflora L. (Myrtaceae). Bradea, 5: $1-10$.

PIVNICK, K. A., 1993, Response of males to female sex pheromone in the orange wheat blossom midge, Sitodiplosis mosellana (Géhin)(Diptera: Cecidomyiidae). J. Chem. Ecol., 19: 1677-1689.

PRICE, P. W., 1984, Insect ecology. Academic Press, New York, USA, 607p.

PRICE, P. W., FERNANDES, G. W. \& WARING, G. L., 1987, Adaptive nature of insect galls. Environ. Entomol., 16: $15-24$.

ROHFRITSCH, O., 1992, Patterns in gall development. In: J. D. Shorthouse \& O. Rohfritsch (eds.), Biology of insect-induced galls. Oxford University Press, Oxford, UK, pp. 60-86.

SCHULTZ, A., 1984, Introdução à botânica sistemática. $2^{\mathrm{o}}$ vol., $4^{\text {th }}$ ed. rev, Editora da UFRGS, Porto Alegre, Brazil.

SINGH, S. D., 1992, On the anatomy and morphology of full grown larva of Amradiplosis allahabadensis Grover (Cecidomyiidae: Diptera). Uttar Pradesh Journal of Zoology, 12: 101-106.

STEARNS, S. C., 1992, The evolution of life hstories. Oxford University Press, Oxford, UK, 249p.

TANG, Y. Q., YOKOMI, R. K. \& GAGNÉ, R. J., 1994, Life history and description of Endaphis maculans (Diptera: Cecidomyiidae), an endoparasitoid of aphids in Florida and the Caribbean basin. Ann. Entomol. Soc. America, 87: 523-531.

WHITHAM, T. G., 1979, Territorial behavior of Pemphigus gall aphids. Nature, 279: 324-325. 